second subclavate, petiolate, sparsely bristly; third cylindrical, bristly; terminal segment subpetiolate, rather blunt, unringed, with about ten separated whorls of bristles. Body ovate from above, anteriorly almost naked, posteriorly with short, sparse bristles; anal tubercle small, bristly, composed of two segments. Both the ventral tube and its processes are cylindrical and stout. Legs stout, bristly; tibio-tarsal articulation constricted. Superior claw finger-shaped, almost straight, not dentate; inferior claw two thirds as long, triangular with straight outer edge. Tenent hairs two. Furcula short and stout; manubrium not exceeding the anal tubercle, sparsely bristly; dentes scarcely tapering, with lateral and ventral rows of separated bristles; mucrones two-thirds dentes in length, long-triangular with entire margins and rounded apices.

Maximum length, I.I $\mathrm{mm}$. Described from ten types.

I found this uncommon species, especially under the bark of dead oak logs, at Arling. ton, Mass., this year, from March 26 until April 12, inclusive. With pleasure I name it after Mr. Samuel Henshaw.

Types of all the above species have been given to the Museum of Comparative Zoölogy at Cambridge, Mass.

\section{EXPLANATION OF PLATE Io.}

Fig. I. Smynthurus socialis, fore foot, $\mathbf{x}$ 472 .

Fig. 2. Smynthurus socialis, mucro, $\mathrm{x} 472$.

Fig. 3. " " hind foot, $47^{2}$.

Fig. 4. Smynthurus socialis, modified male antenna, $x$ i $7 \mathrm{I}$.

Fig. 5. Smynthurus benitus, terminal antennal segment, $\mathrm{x}$ i 16 .

Fig. 6. Smynthurus amicus, fore foot, $\mathrm{x}$ 353 .

Fig. 7. Sinynthurus amicus, mucro, $\times 353$.

Fig. 8. " " hind foot, $x$ 353 .

\title{
PARTIAL LIFE-HISTORY OF HALISIDOTA CINCTIPES GROTE.
}

BY HARRISON G. DYAR, NEW YORK, N. Y.

Larva a large Halisidota, like tesselaris, but dark brown or silver gray brown with all the hair tufts white. Feeding on seagrape, Lake Worth, Florida.

I assume eight stages, though some of them may be omitted in the actual ontogony.

Stage IV. Skin orange brownish, a black subdorsal shade on joints 5 to II, connected dorsally at the ends and most pronounced there ( 5 and $\mathrm{I} \mathrm{I}$ ); tubercles $\mathrm{i}$ to iii black on 5 and II, elsewhere the warts are brownish. Head round, shining black over apex, brown below, labrum bright white; width $1.3 \mathrm{~mm}$. Hair short, thin, white, with a few black ones, especially on the dark marks and on joints 5 and II; a short, yellowish subdorsal pencil on joints 4 and 12 ; a few longer pale hairs at the anterior end. Wart iv absent on the abdomen, leg plate shining; two warts on joints 3 and 4 above the stigmatal wart, one below it; joint 2 considerably retracted. The subdorsal pencil on joint 4 arises from tubercle $\mathrm{i}$; on joint $\mathrm{i} 2$ from iii.

Stage VII. Head red-brown, a little blackish immediately above the white line on labrum and the white bases of the antennae; width $3.5 \mathrm{~mm}$. Hair thinner than in the following stage, the color of the skin visible, violaceous brown with black dorsal shade and spiracular marks or blackish gray, shading darker stigmatically. Hair brown, varying from violaceous brown to chocolate; 
hair pencils as in next stage. A mark in the incisure between joints 3 and 4 pinkish, divided by a dorsal black line and surrounded by black spottings.

Stage VIII. Head round, shining mahogany red, paler along the sutures; a line above the mouth and bases of antennae white; width $5 \mathrm{~mm}$. Hair thick, obscuring the body, uniform pale chocolate brown or gray brown with a whitish cast on the sides, crested and appearing darker along the dorsal line. The hairs separate around the in. cisure between joints 3 and 4 exposing the skin which is here slightly orange tinted, the three upper warts on 3 and 4 being whitish and set off by black patches on the skin. A white hair pencil from warts $i$ and iii on joint 4 , a few long whitish hairs from the same warts on joint 3 ; a white pencil from wart iii on 12. Skin red brown more or less spotted with black or all black except the legs; spiracles white. Joint 2 is retracted, its hairs directed forward over the head. Hairs all finely barbuled; warts $i$ to vi on abdomen; wart iv distinct, but not full size; four warts on thorax. Length of larva about $30 \mathrm{~mm}$. The orange colored incisure on the thorax forms a rather distinct mark, set off by black and the six white rays.

Cocoon. Firm, compact, the larval hairs closely felted and many of them projecting through, so that the cocoon cannot be handled without receiving their sharp points. The cocoon has the color of the hairs.

Food Plants. Sea grape (Coccoloba floridana and C. uvifera), kindly determined by Mr. F. Kinzel. The larvae were found on no other plants and I think their occurrence on Hibiscus, as recorded by Gundlach, must have been accidental or at least exceptional.

The species has a wide range. It occurs in our country in Florida (cinctipes) and Arizona (davisii Hy. Edw.), extending southward through the West Indies and Mexico to Venezuela, through Brazil (interlineata Walk., jucunda H. S.) to Argentina. Moths from Buenos Ayres are paler than Cuban specimens, the marks less contrasted, but all essential features are the same even to the banded legs. The markings on the fore wings are irregular and variable as in $H$. tesselaris.

Doubtless there is some local variation in the larvae in different parts of this wide range. Cocoons from Buenos Ayres are almost black, indicating that the larvae must be considerably darker there than in Florida.

Notes on Lepidoptera.-On cutting open a cocoon of A. luna to see if the pupa was alive, I found that the moth had crawled out of the pupa-skin and, being unable to get out of the cocoon, had laid eggs all over the inner side of it. The eggs were almost black, instead of being white.

For three summers I have noticed that male orioles preferred sphingid larvae to all others, and by following them $I$ have found many larvae of $D$. inscripta, $A$. nessus, and $T$. abbottii, besides $E$. myron. I saw one oriole carry from a woodbine fifty sphingid larvae in an hour and a haif. So far it has been only the male who has hunted in the woodbines, though the female was getting food in elms and ash trees close by.

Each June, for three years a $P$. cardui, has rested on the gravel of our driveway almost every night. It appears between five and six o'clock, settles in almost the same place in the driveway, drops its forewings between its hindwings, and stays quiet until some carriage, person, or dog disturbs it, when it flies about for a few moments, and them settles down again. If an English sparrow flies anywhere near it the butterfly flies towards it, flutters around it as it does around one of its own race, then rests again on the gravel, and is to be seen there as long as there is light enough to see it!

Of course it cannot be the same butterfly, and it is queer that only one should come at a time, and that the resting place should not vary by ten inches either on different nights or years. Caroline G. Soule. 

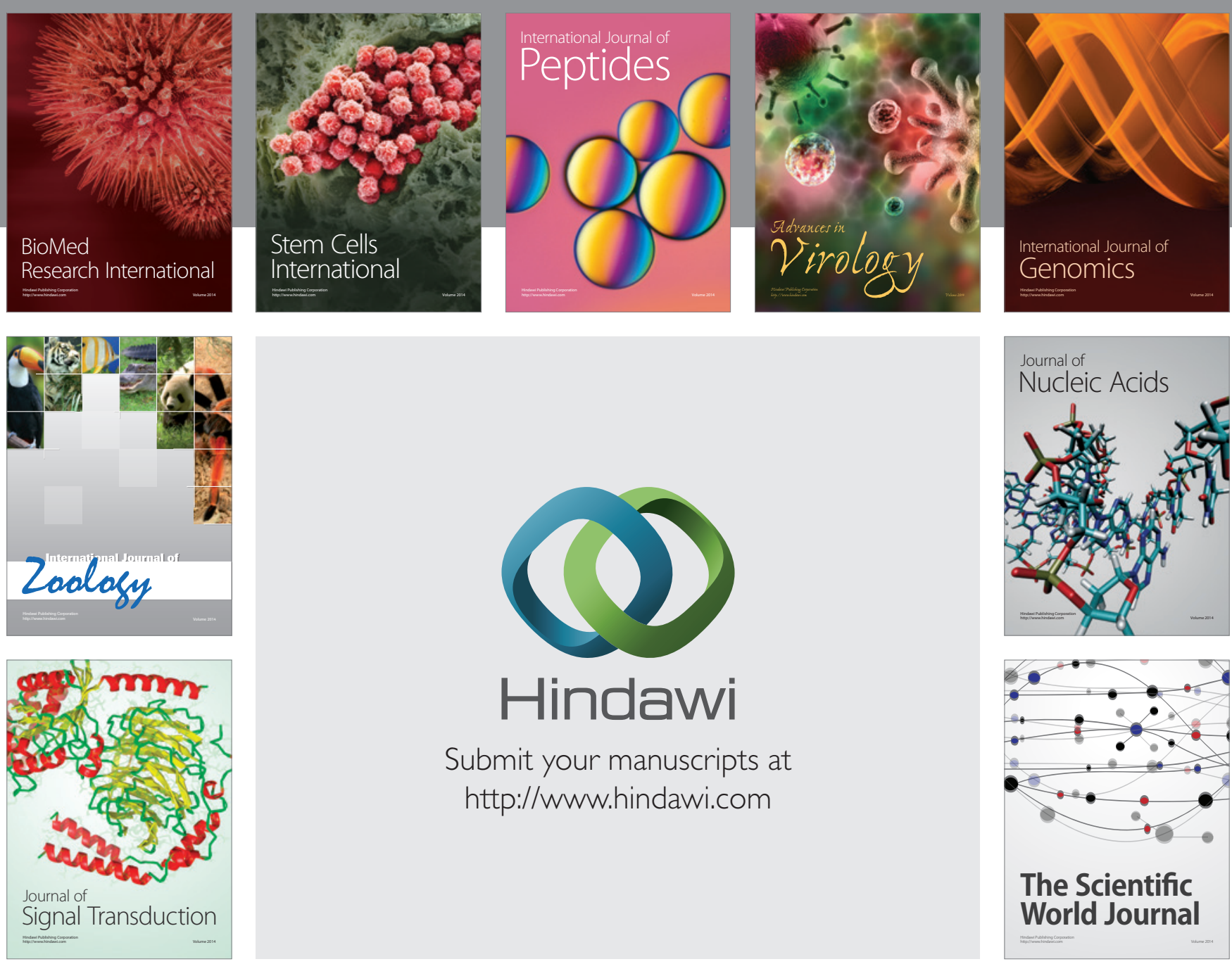

Submit your manuscripts at

http://www.hindawi.com
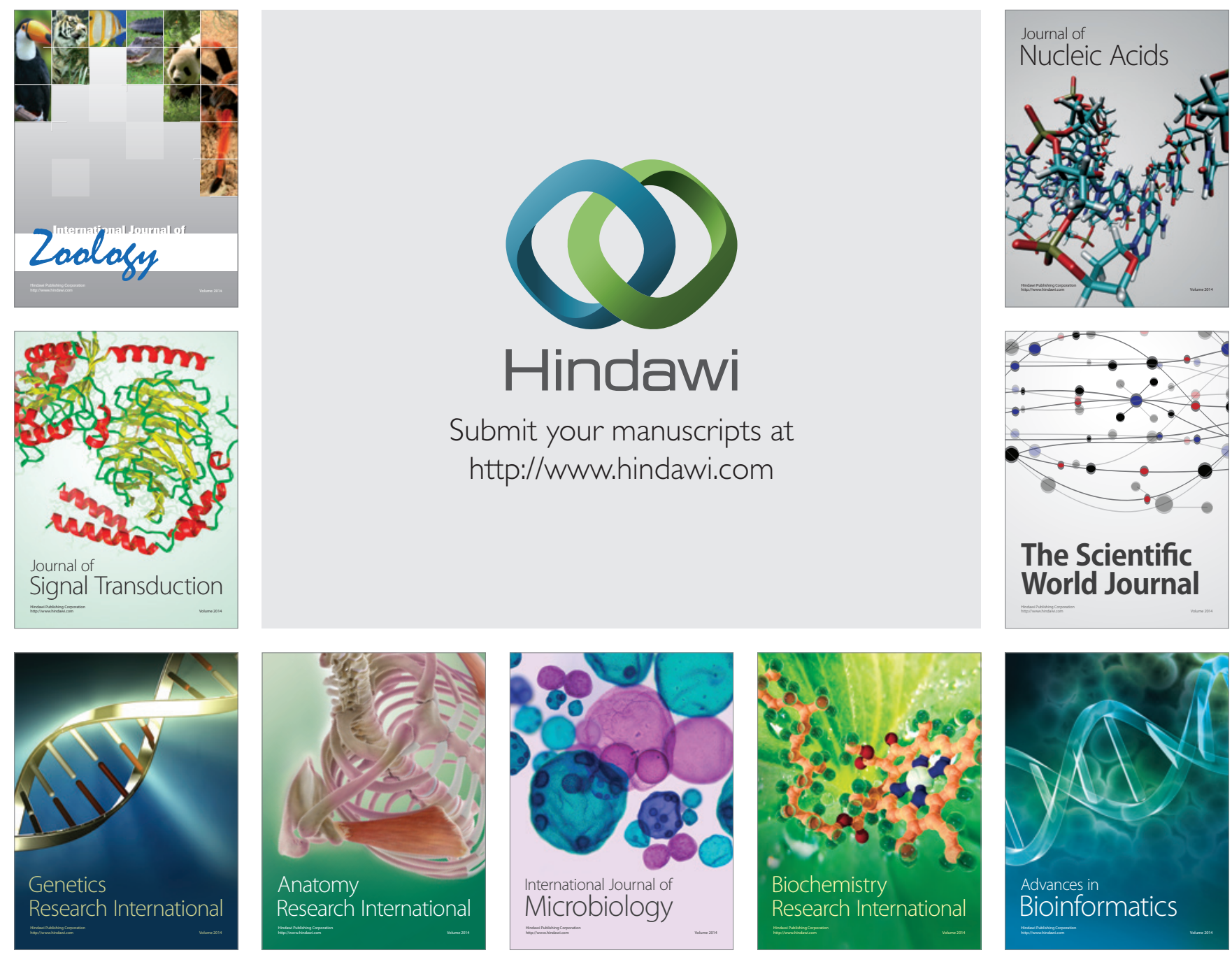

The Scientific World Journal
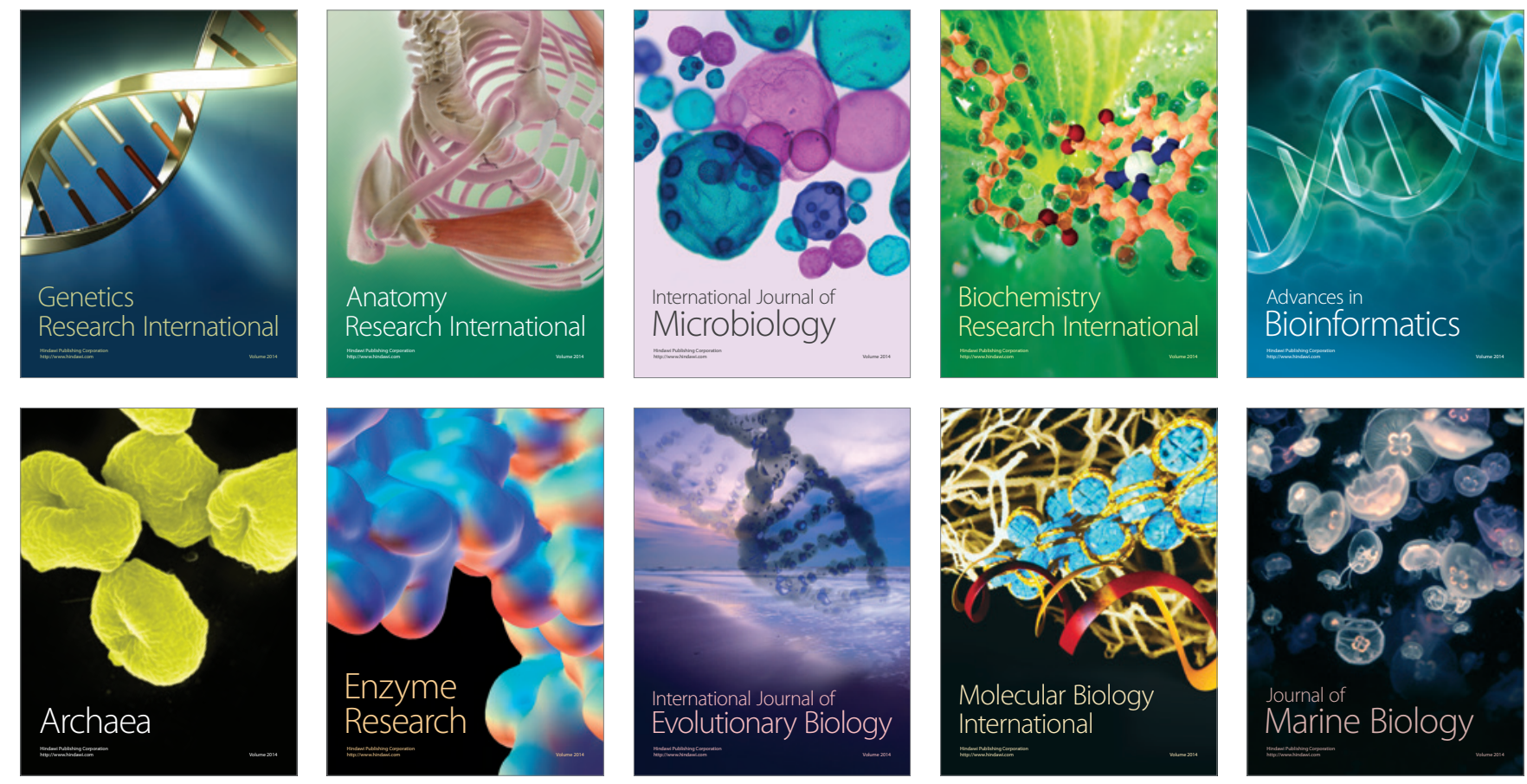